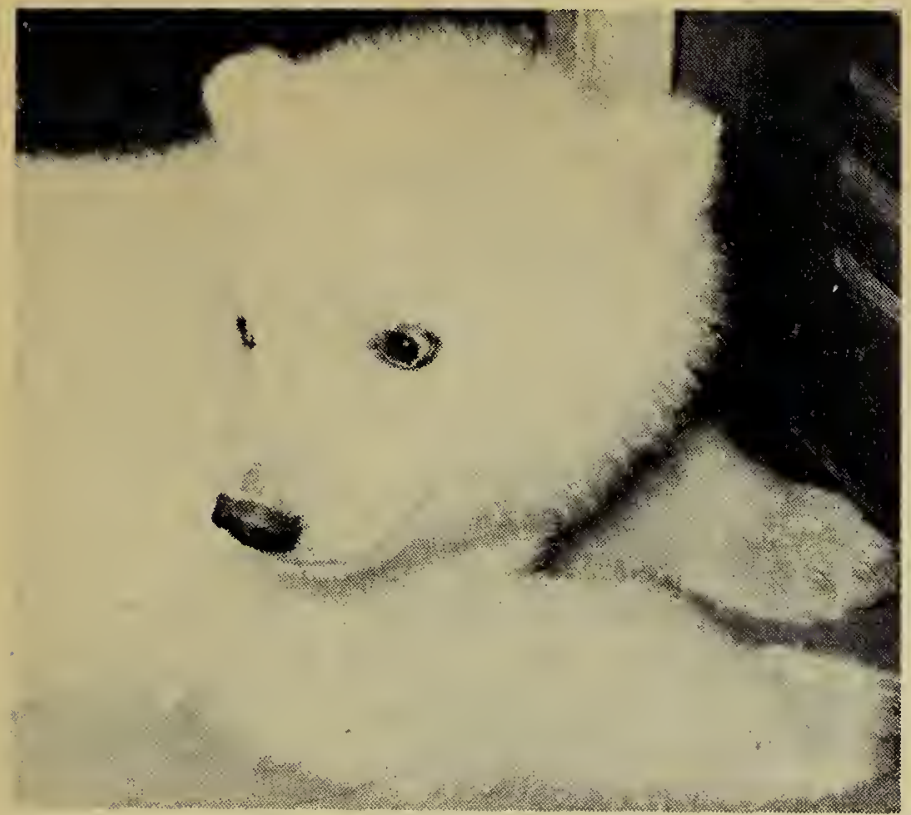

Polar Bear cub.

Peregrine Falcon, Willow Ptarmigan, Sandhill Crane, Ringed Plqver, American Golden Plover, Blackbellied Plover, Ruddy Turnstone, Purple Sandpiper, Baird's Sandpiper, Dunlin, Semipalmated Sandpiper, Red Phalarope, Pomarine Jaeger, Parasitic Jaeger, Long-tailed Jaeger, Glaucous Gull, Herring Gull, Sabine's Gull, Arctic Tern, Thick-billed Murre, Black Guillemot, Snowy Owl, Common Raven, Common Redpoll, Horned Lark, Water Pipit, Lapland Longspur, Snow Bunting.

Mammals: Lemming, Arctic Fox, Arctic Hare, Polar Bear, a weasel, Canibou, Walrus, White Whale, Ringed Seal, Harp Seal, Bearded Seal, Harbour Seal.

\title{
Random Bird Notes From Mexico and the Southwest
}

\author{
by R. D. Symons, Regina
}

Last winter I had the opportunity to follow some of our Saskatchewan birds south of the border on a trip that my wife and I took to Mexico. We left Regina on January 5 and travelled to Chihuahua, Mexico, by way of Lethbridge, and down the east side of the Continental Divide through Great Falls, Cheyenne, Denver, Santa Fe and El Paso.

Through Montana and Wyoming as far as Santa Fe, New Mexico, we encountered stormy weather and had little opportunity to see any birds except Harlequin Dúcks swimming happily about in the rushing waters on the Wind River canyon. At Chihuahua the weather was better, and for the six weeks we stayed there the sun shone continually. However, early January temperatures had been the coldest since the 1880 's, we were told, and almost all of the big palm trees were frozen so severely it was doubted they would survive.

We found that the city parks were good places to see birds, especially Bolivar Park which was right across from the house where we lived en pension. Flocks of grackles roosted in the big dry palm trees and made a lot of noise. The park is well lit and the activity seems to go on all night. These birds imitate the policeman's whistles in a most amusing way.

It is very difficult to get information about birds from Mexicans. They call anything with feathers "pajaritas"-little birds. The vaqueros know the Road Runner as "El paisano"- the Countryman. They know cranes, ravens and vultures, but not much else.

The state of Chihuahua is given over to ranching, and we were invited to stay with an American rancher at Rancho El Eden, 40 miles west of Chihuahua. Around the large springs here are clumps of very old alamos (cottonwoods). They make an oasis in the dry mesquite-dotted foothills and give the ranch its name. To the west the Sierra Madre towers stark and jagged and red. Side oats grama is the prevailing grass, and it was cured to bright Naples yellow. Shrikes are common here and are a regular feature of the landscape as they perch on the top of a prickly mesquite. Each bird sticks to its own territory, which would seem to be about seven or eight acres around its larder bush.

At Quintas Carolinas a group of scavanging Black Vultures looked for 


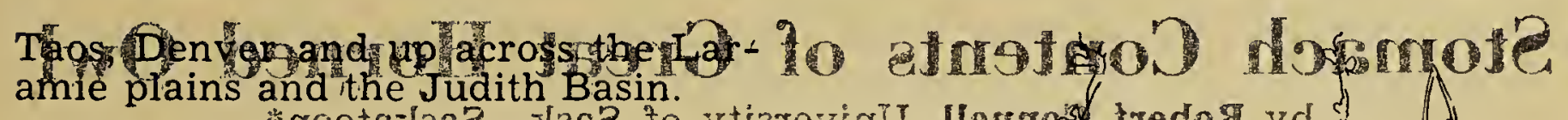

Back on our own plains the first

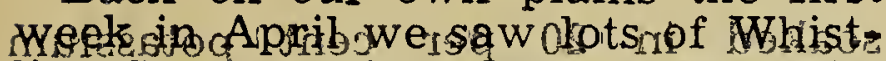

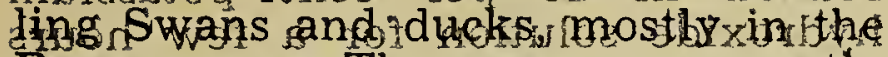
Bassang aread Theoswans were most thy i3 the small ponds becauks thectarges bodies of ivwater weres stil torovered

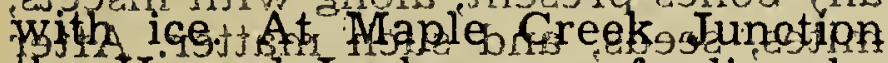

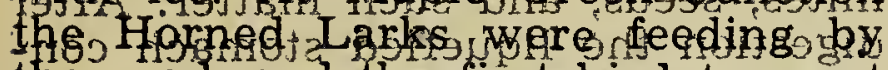

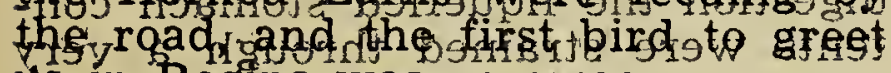
HTin Regina rwasora (crow 00I) эrit viłngg $2.5 W$ no9ro? ort no 9ubiagx .19f6w qat to msayja 6 ni bonasw

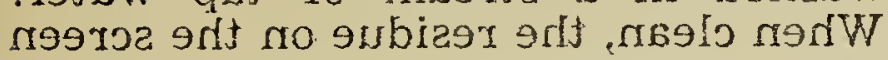
.bomotjod-falt 6 otrit bodesw 2.6W

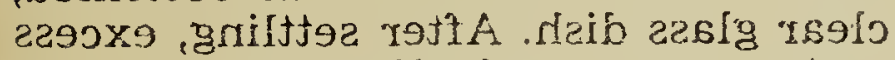

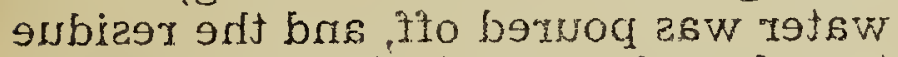

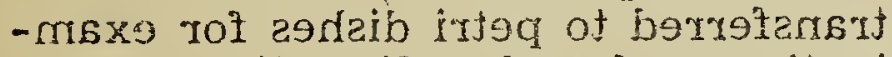
-oroim gnifogezib grts robnu roitsni

.9 qoje

noilsmmsm llerre to noitsolitifngbI allusta nadw fluoittib fon ai anismar ant bobivorq ingagra 9Ts ritsgt bna to ggbolwond $\mathrm{s}$ boriupos asd roxiow git ni zoiteirgtosisho Htagt bris llusa IIsme to z9is9qa 9vitsu frovetlib

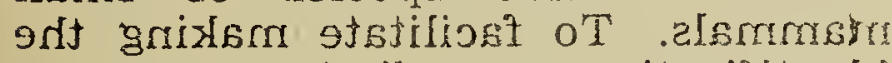
s b9isq9xq ferit $9 \mathrm{~W}$ enorissitismabi IIsma to rifggt bris alinka giff of vart

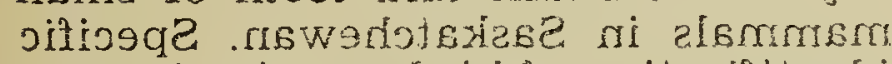
9Tom ai anismax brid to noitsoifitngbi

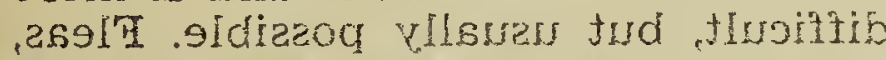

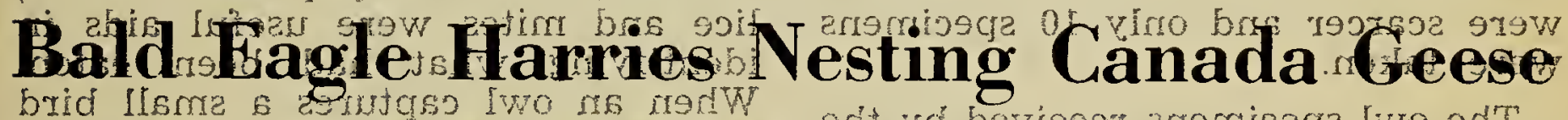

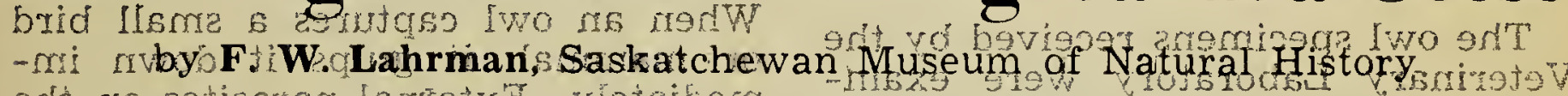

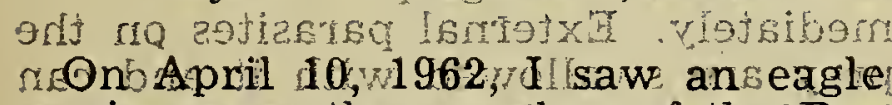
soaringover the marshes of the Red gina Waterfowlg Park and coming ito land onlone of the mounds of the dugout There 1 could odentify it as an Hmature Bald Eagle. Two days later, on April 12 ; I again noted the eagle atrthe manshiwhen I first saw it it was soaring high in the sky; then it began to circle down toward the nest of a Canada Goose on a muskrat house in the marsh I wondered how the pair of geese would react, so I turned to look at them I could see that the geese were? nervous the goose on rithe nest had her neck stretched out flat, and the gander on a dyke approximatelyrion yards artay was also crouching flat with outstretched neck

As the eagle drew closer, the goose slipped off the nest, calling to the gander The eagle swooped at the goose which dived under water and then it hovered over the water wait-

ing for the goose to reappear The alerted gander came fly un swiftl to her rescue It flew directly at the e a gle and the surprised eagle turned aside to escape attack Apparenty the gander struk at ine eagle with its wing, but fogmon' see whether it actually, hiterthe eagle. Then it flew obyoncled and attempted as second attack but the eagle escaped by climping swiftly in toithe air After flying some distance the eagle came down to land on the ice st sat there for a few minutes, and then flew up again to go to an ather nest. Here, tog the goose slipped off the nest and she and the gander standing beside the nest both stood with outstretched wings, honking loudly The eagle flew off soared into the air, and away What was presumably the same bird was noted brieflythe following day soaring over the marsh routrit was not seen a gain molesting the geese. 